\title{
Identity Transformation of Migrants from Bosnia and Herzegovina in post-1960s Germany*
}

\author{
AMIR DURANOVIĆ** \\ Faculty of Philosophy, University of Sarajevo
}

\begin{abstract}
Results presented in this paper are part of an extensive research in $\mathrm{BiH}$ emigration of the second half of the $20^{\text {th }}$ century conducted during a field trip in Berlin, Germany. This paper aims at presenting the foundations from which the emigration originated after the Second World War and then changes which occurred during the 1960s when a large number of people from Yugoslavia and Bosnia and Herzegovina left for temporary employment in Germany, Austria, Switzerland and other Western European countries, as well as to look into models and reasons for the transformation of identity of $\mathrm{BiH}$ migrants in Germany after the 1960s. With the aim to identify the pattern according to which the workers with temporary employment abroad created their identities, this paper dedicates special attention to the transformation of identity, i.e. it indicates how identity transformed under the changed circumstances and in an altered context. However, research focuses on a part of $\mathrm{BiH}$ emigration in Germany, West Berlin in particular, since it stands out as a special case, an enclave in East Germany. Therefore, the presented examples of identity transformations of $\mathrm{BiH}$ workers in Berlin that were followed by changes in their native country, Yugoslavia, i.e. Bosnia and Herzegovina, but also by the changes Germany experienced the end of the 1980s. Finally, the paper aims to show the multi-layered identities and their changes from the working, religious, social to the national identity.
\end{abstract}

Key words: Bosnia and Herzegovina, Yugoslavia, Germany, Muslims, Bosniaks, workforce, migrations, socialism, identity transformation.

\footnotetext{
"This is an extended and edited version of a paper first published in German language as "Das religiöse Leben der "Gastarbeiter" aus Bosnien-Herzegowina in Deutschland in den 1970er und 1980er Jahren”, Südosteuropäische Hefte, Jg. 3, Nr. 1 (2014), 67-77. Research was conducted within the Project entitled "Repräsentationen des sozialistischen Jugoslawien im Umbruch" at the Humboldt University in Berlin, Germany.

"PhD. History Department. Email address: amir.duranovic@ff.unsa.ba
} 
Research results presented in this paper are part of a broad research project about $\mathrm{BiH}$ emigration in the second half of the $20^{\text {th }}$ century. The subject of $\mathrm{BiH}$ emigration was treated and elaborated in a number of studies and papers, but the quality of written scholarship is still to be revalued within the possibilities offered by the primary sources. Therefore, our topic in a narrow sense, and the topic of emigration in a broader sense, require additional research efforts. With this paper, we will exclusively focus on the religious life of Yugoslav/Bosnian Muslims and their organised activities within a community - jamaat, and the transformations of multi-layered identities in the circumstances mainly shaped by major social and political changes in Germany, where they lived and worked, and Yugoslavia/Bosnia and Herzegovina, where they came from. From the $\mathrm{BiH}$ perspective, the issue of migrants has been discussed in many historiographic papers treating several different thematic units. The focus has mostly been on migrations of the Muslim population after the Congress of Berlin in $1878,{ }^{1}$ but other topics have not completely been neglected, either. Historiographic studies regarding migrations towards Western Europe are rare and the existing ones mainly focus on individual, concrete research problems. Thus, for example, in his study Bošnjaci u emigraciji [Bosniaks in Emigration], Mustafa Imamović focuses on the activities of Bosanski pogledi [Bosnian Views], a migrant journal edited and published by Adil-bey Zulfikarpašić during the 1960s, whereas other questions remained without an adequate answer. ${ }^{2}$ Results of certain research endeavours in the last several years, with a special focus on the workers, raise hope that the issue of emigration from the former Yugoslav area and, therewith, from Bosnia and Herzegovina, can be adequately treated in historiography. In that sense, Vladimir Ivanović presented research results in a unique monograph, which are of particular value. ${ }^{3}$ In separately published papers, Ivanović directed the attention of the scholars towards certain significant issues from the life of the working population, such as the issue of everyday life and free time,

\footnotetext{
${ }^{1}$ Bandžović 2006. About the topic with different views of key issues see: Pezo 2013.

${ }^{2}$ Imamović 1996. It is important to say that these are not the only studies which treat the issue of Yugoslav, i.e. $\mathrm{BiH}$ emigration. Considering the degree and dynamics of the formation of migrant circles in Europe, America and Australia, it is necessary to mention that those circles were formed in several phases and that the Yugoslav government had ample information about their organisation and activities. During the 1970s, the Yugoslav political leadership talked about more than 20 ustasha, 15 chetnik, 15 Albanian, 8 Slovenian and 2 Macedonian organisations. If we take into account those groups and their activities, it is also necessary to highlight one of the conclusions of Imamovićs study according to which the $\mathrm{BiH}$ emigration, including thus the Bosniak emigration as well, was mostly split between the Croatian and Serbian emigration, and that to a certain degree explains the lack of other studies whose main interest would be directed towards Bosniaks. A similar conclusion about "Muslim political organisation" can be found in: Doder 1989, 127.
}

${ }^{3}$ Ivanović 2012. 
usual topics in modern ethnographic, anthropologic and historiographic literature. ${ }^{4}$ The issue of everyday life and free time as a research problem is especially valuable, since, according to Ivanovićs research, the majority of the working population was relatively satisfied with working conditions, levels of income, etc. The problems this population was significantly facing were those concerning free time and socialising after work. At this point, the research space is open to our topic since the issue of religious life is closely connected to everyday rituals, behaviour and filling free time with certain social activities, thus leading to the transformation of identity markers of individuals and groups. While examining the available literature and during the research conducted in Berlin, we have determined that the issue of religious life of the working population should be approached in a broader sense than from a simple ritualistic practicing of faith, i.e., the religious life implies activities which include a sense of belonging to a certain community, cultural activities, humanitarian work, sport activities, etc.

Beside the abovementioned titles, it is important to emphasise that the context of dissolution of Yugoslavia, apart from increasing migration waves towards the countries of Western Europe, also increased researchers' interest in BiH emigration. In that respect, author Alaga Dervišević published several articles with a special focus on the emigration of Bosniaks. Complete results of his work, presented in the first of three published volumes of the book Bosnjaci u dijaspori [Bosniaks in Diaspora], remained rather confusing since they do not provide a significant assistance in the research of this topic. ${ }^{5}$ It is evident that the once open question of emigration is still attractive for researchers and that every achieved result in this direction offers at least a part of the answer to many questions which still remain open. Thus, we welcome the scholarship focusing on Bosnian communities in Germany, its orientations and activities in transnational social spaces, ${ }^{6}$ or papers focusing on Bosniak personal networks in Berlin and their discourse. ${ }^{7}$

When referring precisely to the subject of religious life in Bosnia and Herzegovina in Germany in the second half of the $20^{\text {th }}$ century, except for a few papers published in the last several years, there has not been a paper that could serve as a starting point for research or as a model to be used to adequately present the topic. Information about the religious life of Bosniaks in Germany, but also in other parts of Europe and America, originate from the organisational structure of the Islamic Community in Bosnia and Herzegovina and mainly represent a set of basic data in every organisational unit, such as the place of activity, members of the governing body,

\footnotetext{
${ }^{4}$ Ивановић 2011, 69-87.

${ }^{5}$ Dervišević 2006.

${ }^{6}$ Paul 2016.

${ }^{7}$ Мандић 2018.
} 
a short overview of activities, the number of members of the community, the basic information about the official who is head of the community, etc. ${ }^{8}$ We consider this kind of information, even though published in the form of a book, a monograph, some kind of a source basis four our research.

From the mid-1960s until today, the so-called temporary economic migration has to a great part become a basis from which minority communities formed and exist today in almost every country of the Western Europe. Already by the 1970s, first attempts at organised actions were recorded. Groups of workers who lived and worked in German cities expressed the wish for an organised religious community. Initialdifficulties were overcome with religious officials from Bosnia and Herzegovina or other parts of Yugoslavia coming in to help organise religious life. Very often, they were young students form the Faculty for Islamic Studies in Sarajevo (founded in 1977) or madrasah graduates (Islamic secondary schools). In 1978, Aachen was the first German city to see the establishment of a community in Germany by the workers from Bosnia and Herzegovina, while others were mainly formed during the late 1980s or in the early 1990s. ${ }^{9}$ It is important to emphasise at this moment that the organisation of religious life during the 1970s was to a significant extent defined by the number of working population. Thus it happened that workers from Bosnia and Herzegovina, lacking their own community, satisfied their spiritual needs in the communities of other ethnic groups, most frequently, Turks. ${ }^{10}$ We received similar information while interviewing Bosniaks living in Berlin since early 1970s, from whom we learnt that the majority of workers form Bosnia and Herzegovina led their religious lives "trough Turks". ${ }^{11}$ But a higher concentration of Muslim workers from all parts of Yugoslavia (Bosnia and Herzegovina, Croatia, Serbia, Montenegro, Macedonia) in one place enabled the formation of new communities which could be said to have had the Yugoslav attribute. ${ }^{12}$ Such a situation lasted until the dissolution of Yugoslavia, when the models of organisation changed. ${ }^{13}$ Today, there are 57 communities (jamaats) in Germany, 47 of which have a religious official, employed fulltime, leading the community. The rest are the so-called weekend jamaats where officials are hired part-time. In the organisational sense, there is one main imam for Germany with associates-coordinators in parts of Germany, in the following regions: Nord, Bayern, Berlin (and the region of former GDR),

\footnotetext{
${ }^{8}$ Mahmutović 2003.

${ }^{9}$ Ibid., 128-129.

${ }^{10}$ Ibid.

${ }^{11}$ Interview with M. K., Berlin, 25 July 2013.

${ }^{12}$ Mahmutović 2003, 130.

${ }^{13}$ Ibid.
} 
Nordrhein-Westfalen, Hessen and Baden-Württemberg. ${ }^{14}$ Activities towards the state institutions, regardless of the level of government, are defined in the document The Platform for Activities of the Islamic Community of Bosniaks in Germany (the German name of the institution reads: Islamische Gemeinschaft der Bosniaken in Deutschland-Zentralrat e. V.). ${ }^{15}$

To follow the development of these communities, jamaats, means to follow the private lives of Muslim workers from Bosnia and Herzegovina and other parts of Yugoslavia. Their private association grew with time into an attempt at organising a community for servicing the spiritual needs of Muslims and this would most frequently happen during the month of fasting - Ramadan. In several cases we notice that the initiative for the establishment of the community stemmed from a group of individuals, for example, in Dortmund, Essen, Duisburg, Frankfurt am Main and others. ${ }^{16}$ In this way, the jamaats that today exist were established over the period of three decades and have been integrated into the Islamic Community of Bosniaks in Germany. Out of 47 jamaats, each employing one religious official fulltime, three were formed in the 1970s, 15 in the 1980s, while most of them, 28, were formed in the 1990s, and only one at the beginning of the new millennium, in 2001. ${ }^{17}$ In percentages, it means that during the 1970 s $6.40 \%$ jamaats were formed, $31 \%$ during the 1980 s, $60 \%$ during the 1990 s and $2.6 \%$ during the 2000 s. We can thus conclude that over a half of the jamaats (almost $2 / 3$ of the total number) was formed during the 1990s when the number of people from Bosnia and Herzegovina in Germany increased due to war circumstances, since they came to Germany as refugees. Research about their identity markers, migrant discourse and networking is an important step in gaining a better insight into the identity transformation of Bosnian/Bosniak communities in Germany, ${ }^{18}$ particularly in the city of Berlin. ${ }^{19}$

Nevertheless, the focus of this paper is the communities formed during the 1970s and the 1980s, since temporary workers in Germany constituted their basis. The initial phase of the organisation of each community implied difficulties regarding the issues of space where the community could act and other similar problems. In most cases, the problem was solved through joint efforts with other Muslim communities, most frequently Arabic or Turkish. In cases when the religious life only concerned the working population from Bosnia and Herzegovina or other parts of Yugoslavia,

\footnotetext{
${ }^{14}$ Ibid.

${ }^{15}$ Platforma za djelovanje Islamske zajednice Bošnjaka u Njemačkoj: http://igbd.org/?p=3151 (Last accessed on: 1 November 2020)

${ }^{16}$ Mahmutović 2003, 145, 147, 149 - 151.

${ }^{17}$ Ibid., passim.

${ }^{18}$ Paul 2016.

${ }^{19}$ Мандић, 2018.
} 
the initial spaces for performance of basic religious rituals were places where such population lived. These were the so-called heims, wooden barracks for the collective accommodation of the working population in Germany. ${ }^{20}$ For example, before the establishment of the community in Frankfurt am Main, Abdurahman Hukić of the High Islamic Council, together with Kasim Osmić, imam during the month of Ramadan in 1977, visited a group of Muslim workers from Yugoslavia. The first common prayer during Ramadan was held in working barracks, and the initiative for the official establishment of a community was implemented with the registration at city authorities in $1979 .{ }^{21}$ The month of Ramadan, a period of especially accentuated religiousness of Muslims, was the time when the initiative for the establishment of communities started in other places as well. As with the previously mentioned example, the establishment of the community in Hagen, in 1988, was the result of a private initiative of a group of workers who had made a decision about the establishment and court registration. ${ }^{22}$ These examples, but also the examples of other communities, illustrate the connection of the working population with the native space, homeland, but also the position of official institutions such as the High Islamic Council which, during the 1970s, began a more active engagement aimed to provide the basic preconditions for the organisation of religious life among the workers from Yugoslavia. The intensity of activities changed with time, the previously presented statistic indicators confirm this, hence, during the 1980s, the number of organised communities significantly increased. These changes coincide with changes in the organisation of clubs i.e. associations. While, in the 1970s, the clubs had the Yugoslav attribute, during the 1980s the situation changed the way that clubs were organised on ethnic bases. Regarding the organisation of clubs, it is important to emphasise that this aspect of common life and action went through several different phases during the 1970s and 1980s, so there were several challenges because of the clubs' activities and their relationship towards Yugoslavia, i.e., the creation of the Yugoslav image in Germany. ${ }^{23}$ Clubs and associations of emigrants were places where workers were presented with the image of a different Yugoslavia than the one they had known as their homeland.

Our interlocutor from Berlin recalled his experience with the Ustasha emigration during the 1970s. Namely, as a young qualified worker from Bosnia and Herzegovina who arrived in Berlin in 1970 and started working for BMW, he befriended the workers from other parts of Yugoslavia, not only from Bosnia and Herzegovina.

\footnotetext{
${ }^{20}$ Ivanović 2012, 220 etc.

${ }^{21}$ Mahmutović 2003, 151.

${ }^{22}$ Ibid., 154.

${ }^{23}$ Ivanović, 2012, 240-252.
} 
"I complained to a man from Herzegovina, from Ljubuški, (that a German doctor would not give me a sick leave); I didn't even know that Ljubuški existed in Bosnia then, and he gave me the address and said, go, there is a doctor, he is our man, speaks our language, he is a Yugoslav, do not tell him anything hurts you, just tell him 'I need a sick leave' and he will give it to you. And I accepted that. When I went there, I found the address, it read 'Dr. Jelić' [...] But he (dr. Jelić) welcomed me in a manner I found surprising. I know that my father loved me more than anyone else, but he had never welcomed me like that. In the end, he said to me 'here you are, my son' and he gave me two books. Read these in peace. And I took the two books, I will take them, I said, what else should I've done. I was carrying them on the way home, on the upper deck of the bus, got two weeks of sick leave, opened, started reading... Hmm, there was something unusual, but interesting. And as I had read several pages, I realised that my companions [other workers with whom he was living] should not know of it. I immediately realised that I had to read covertly, so that no one sees it. As I was reading more and more, I cannot recall it all now, but there were interesting things, and then some of their propaganda, like 'Tito is not the Tito at all; the true Tito doesn't have a hand, a finger; Tito is installed, this is not the real Tito. This Tito killed a number of Muslims and Croats after the war, partisans killed a number of people after the war' and so on... There were some numbers, thousands, confusing me a bit. I could not understand it because I had come from Yugoslavia where Tito was, almost, astagfirullah [May God forgive me], we were to swear by Tito, and these people here wrote such things. But then, it became interesting to read, to go back several times, but so that nobody found out (...) And I kept it, hid it, but then the news spread that the Yugoslav UDBA [secret police] assassinated the doctor." ${ }^{24}$

The situation in the 1970 s and, to a certain extent, in the 1980s started to change in the time when the dissolution of Yugoslavia had become apparent. "When Yugoslavia broke up, everybody was interested in what was going on, in the elections, the party ... and then Jelić came to me (the memory of Jelić), many things came back to me, oh mother, where we had found ourselves. I understood that there was some pressure, that we should open our ears widely, to listen, and believe me or not, it was only after 20 years of my stay here that we all from the so-called holes came out with the question of where we were, who we were. And only then have I truly met the people from Bosnia, I mean Bosniaks, Muslims. After 20 years! The circle of people I had known before was narrow, but then it broadened, and then the idea was born, of a mosque, of a club...."25

\footnotetext{
${ }^{24}$ Interview with M. K., Berlin, 25 July 2013.

${ }^{25}$ Ibid.
} 
The dissolution of Yugoslavia and the wars in the territory of the former common state caused a great number of forced changes of places of residence and, along with the changes of the demographic structure in successor states of former Yugoslavia, the migrant communities in the countries of Western Europe evidently grew. A significant number of countries offered sanctuary and accommodation for $\mathrm{BiH}$ refugees, opening thus a space for spreading of the then-present, mainly working communities. Such was the case with Germany and its capital Berlin where, before the formal unification of Germany, preparations were made for the organisation of Bosniaks into a unified community. They gained the official right for publicity and formal visibility through the formation of the Islamic Cultural Centre of Bosniaks in Berlin on 10 September 1989, and in February 1990 the association was registered at the court. ${ }^{26}$

Changes in the structure of the Bosniak community in Berlin, as well as the context of the dissolution of Yugoslavia, influenced the change in presentations of Yugoslavia, thus leading to further identity transformations. The former relationship towards Yugoslavia as the common homeland was changing in the time of Yugoslav wars. As the aim of this research and paper is to examine the structure of the Bosniak community in Berlin, organised within the Islamic Cultural Centre of Bosniaks in Berlin (Islamisches Kulturzentrum der Bosniaken in Berlin) and the presentation of Yugoslavia within this community, it was necessary to additionally survey the mood among Bosniaks regarding Yugoslavia and establish the causes for the change of images of Yugoslavia. Even though the present official name of the Bosniak community is Islamic Cultural Centre of Bosniaks in Berlin, this was not the case from the beginning. Actually, the analysis has made possible to understand the extent to which changes of the German and Yugoslav context influenced changes in the name of this association, meaning that the change of social and political relations followed and at least twice influenced the identity of Bosniaks assembled in Berlin. During the first court registration, the association was formed as the Islamic Religious Community of Yugoslav Muslims in West Berlin (Islamische Glaubengemeinschaft Jugoslawischer Moslems in Berlin West, e. V) and was officially registered on 9 February 1990 . From the court register, it is evident that the first statute of the association was adopted on 5 November 1989, and that it was changed on 7 January $1990 .{ }^{27}$ From the initial religious identity of Yugoslav Muslims, exclusively linked to West Berlin, the first identity transformation was connected to social and political changes of the German context where members of this community lived. Namely, after the unification of Germany and therewith that of Berlin, a second phase followed, i.e. the change of name under the new

\footnotetext{
${ }^{26}$ Amstgericht Charlottenburg, Vereinsregister, VR 10141, blatt 1.

${ }^{27}$ Amstgericht Charlottenburg, Vereinsregister, VR 10141, blatt 1.
} 
circumstances. The association changed its name to the Islamic Community of Yugoslav Muslims in Berlin (Islamische Gemeinschaft Jugoslawischer Muslime in Berlin, e. V). Besides this change, caused by political changes in Germany, it is evident that the word "Moslems" (in German) was replaced with the word "Muslime" which also corresponds to the context of changes in the language use in English/ German and general treatment of Muslim communities in Europe. However, there are still academic debates on how to name Muslim communities in European countries. What is certain is the fact that changes in the academic discourse happened during the 1980s. One of the explanations of this linguistic transformation is possible to link with the increased influx of Muslims to European countries from former European colonies and as Muslims themselves prefer the name "Muslims" rather than "Moslems", it can be concluded that the linguistic transformation is actually the result of the confrontation of former colonists with their colonising past. ${ }^{28}$

The third change in the name was caused by changes in the Yugoslav context, i.e. by the fact that Yugoslavia broke up. The community changed the name to the Islamic Cultural Centre in Berlin (Islamisches Kulturzentrum in Berlin e. $V$ ) thereby erasing every association with the Yugoslav origin of the community members, while, at the same time, the community received its universal character and could theoretically be perceived as a Muslim community, regardless of the regional or ethnical origin of its members. Also, the statute of the association again underwent certain changes. $^{29}$

Finally, in 2006, the association adopted its official name, in use today - the Islamic Cultural Centre of Bosniaks in Berlin (Islamisches Kulturzentrum der Bosniaken in Berlin e. V). The fourth renaming was the result of stabilisation of organisational circumstances within the association after the 1990s, mainly marked by the relationship towards the events in Bosnia and Herzegovina, and the very name of the community should be understood in the context of solution to the identity transition from the "Yugoslav-Muslim" identity to the present, "Bosniak"

\footnotetext{
${ }^{28} \mathrm{Also}$, it is possible to discern in the title that the second variant does not include the word "religious" but "Islamic community". This is a transformation which occurred in the history of the Islamic community already by the 1960s, i.e., in 1969, when the Constitution of the Islamic Community was adopted, thereby erasing the term "religious" from the title. Arguments of advocates of these changes were of practical nature because they considered that term "Islamic" implied the term "religious". On the other hand, this change occurred at a time when the process of political affirmation of Bosnian Muslims in a national sense was well under way, and this was an issue debated broadly on the forums organised by the League of Communists of Bosnia and Herzegovina. The Party leadership of Bosnia and Herzegovina thought that, with these changes, the Islamic community wanted to broaden its activities outside of the "religious" domain, which would be against the basic principles of the League of Communists of Bosnia and Herzegovina. See more: Kamberović 2011, 180-208, also Duranović 2015.
}

${ }^{29}$ Amstgericht Charlottenburg, Vereinsregister, VR 10141, Blatt 1. 
identity. ${ }^{30}$ This more detailed elaboration about names of the association was necessary in order to understand the influence of different contexts on one, still small community, whose activities and relationship towards Yugoslavia in the time of its dissolution still remain the focus of this work. Therefore, in the remainder of the paper we are going to consider in more detail the influence of war events in Bosnia and Herzegovina on the perception of Yugoslavia among the Bosniaks gathered in the ICC Berlin.

Besides the already-elaborated issue of names of the association-community, the timeframe in question requires introducing another important aspect of the complete context, which determines forms and shapes of the association and ways in which the community functioned in the conditions when, until the 1990s, it had mainly been the community of migrants-workers from Yugoslavia, considerably enlarged by the influx of a significant number of refugees from Bosnia and Herzegovina, who arrived to Germany, i.e. Berlin. Even though their identities matched in a number of determinants, there was still a significant identity difference with respect to the reason of their presence in Germany. Considering the wider European context, i.e. the fact that the majority of the then-present working communities in the countries of Western Europe were enlarged by a significant number of refugees, in comparison with examples from other countries, a comparative approach would be advantageous, aiding to gain in that context also a more quality insight into the organisation models in different countries. Certain research on the organisation of the "Bosnian community" in Great Britain already exist, whose methodological approach, as well results can be useful for research of the community in Berlin. ${ }^{31}$ In the mentioned paper, Kelly Lynette basically differentiates the working and the refugee identity of community members, taking into consideration the different status towards the legislature of the country they inhabit, but also emphasising certain similarities, i.e. questions and problems that are equal for all community members. Finally, the importance of the host country's policy towards the events in the country of origin of the members of a certain community should not be neglected, since this aspect also reflects among the members of the community. ${ }^{32}$

The greatest indicator of changes which influenced the perception of Yugoslavia was its dissolution. The organised activities of Bosniaks gathered around the Islamic Cultural Centre of Bosniaks in Berlin, i.e. the "Centre", as they themselves call their institution, ${ }^{33}$ was mainly directed towards Bosnia and Herzegovina and events there.

\footnotetext{
${ }^{30}$ Amstgericht Charlottenburg, Ausdruck Vereinsregister, VR $10141 \mathrm{~B}$.

${ }^{31}$ Lynette 2003, 35-49.

${ }^{32}$ Von Oppen 2006 192-210.

${ }^{33}$ Self-perception also plays an important role in understanding the identity of this community. Especially since within the circles close to the Islamic Cultural Centre the first work, treating the
} 
From the contemporary point of view, at the beginning of the new millennium, the leadership of the Centre started planning new directions for action since, until 2010, when the last debts were paid for buying the premises in Kreuzberg, the Centre primarily focused on strengthening its own internal structure and on the actions towards Bosnia. Everything that happened during the 1990s was exclusively directed towards Bosnia and Herzegovina since "the complete work of the Centre during the war was directed towards Bosnia - help for Bosnia, humanitarian aid, offering help for refugees who arrived here from Bosnia, appeals for help for Bosnia. And then, in 1995, there was a traumatic experience here at the Centre. After Srebrenica (Genocide in Srebrenica), many women with children came here, and they hoped for a long time that their husbands had survived (...), here it was a complete traumatisation of a generation in Berlin. This space was a place where they could come and communicate, help each other, complain to each other and that was a way for healing their war trauma." 34

The mentioned aspects of activities of the Centre were at the same time the main determinants which directed the change of the flow of opinions towards Yugoslavia. The dissolution of Yugoslavia destroyed the unique picture of the Yugoslav identity which had existed until then among the Gastarbeiter population. Namely, testimonies of active participants of changes which they went through show how it was possible to clearly differentiate one perception of Yugoslavia until the 1990s and a completely different one after the break up of the country.

"Muslims from Yugoslavia were very proud of Yugoslavia, of a strong country. Everyone was proud of that 'red passport'. Being a Yugoslav was something huge. And Yugoslav Muslims had a lot more here than other working or migrant communities. They had a significant freedom of movement that made them proud (...) and those Gastarbeiters were organised trough a number of cultural societies. There was an association 'Boro and Ramiz. And they were more tied to the country, and less to religion. Yugoslavia was present here through the Military mission; there was an organised school of the native language. And with older people, you could see how proud they were of that country (...). I think that the term 'diaspora' was not in use then. It came later. ${ }^{\text {' }} 35$

Apart from the aforementioned, a positive image of Yugoslavia among the older generation should also be linked to a better understanding of the Yugoslav

issue of this community in an imaginary world - the world of a novel - was written, but the plot, the perception of characters and the overall context were marked by the authentic experience of the community members. Ćehić 2010.

${ }^{34}$ Interview with M. T, Berlin, August 2014.

${ }^{35}$ Ibid. 
circumstances and a different experience of the Yugoslav state. The fact that the majority of those people came from Yugoslavia to Germany because of economic reasons should also be taken into consideration. Finally, it is important to emphasise their social and educational structure which certainly influenced their attitudes towards Yugoslavia, socialism, i.e. social and economic relations in general.

"I think that people here had no special relationship towards socialism and the idea of socialism. It is important to understand the structure of those people, mainly workers, and their interest for the economic system that was reduced to whether or not they had work and how they lived from it. They were not interested in things which they found here in an ideological sense, the issue of freedom of speech etc., I think they were not even interested in it and they did not think about it at all. And they did come here because of work. And their Yugoslav origin also speaks of their aim. They are the people who arrived from economically underdeveloped areas and that defined them. And so they come here, become enchanted by ordinary things because, for the first time in their life, they come to urbanised areas, arranged streets, etc. They did not think about big ideological issues because, somehow, they were not raised to be interested in great things and great issues and it caused a certain indifference towards ideas. That is something you still have here among Bosniaks." ${ }^{36}$

Apart from the mentioned attitude towards socialism, generalised to a significant extent, it is important to emphasise the way in which the perception of socialism functioned among ordinary workers from Yugoslavia. Yugoslavia was often viewed through the prism of the most notable personality of the Yugoslav history in the second half of the $20^{\text {th }}$ century. A significant number of working population in Berlin believed that they were in Germany only for a temporary stay - work, and the vision of Yugoslavia through the personality of Josip Broz Tito defined the basic perception of socialism. "However, respecting J. B. Tito carried weight, they had a positive attitude towards Tito and through him towards the state. On the other hand, here in East Berlin, there was a socialism different from the one which they were familiar with in Yugoslavia. There, it was interesting for them to see the big $\mathrm{TV}$ tower, go to a restaurant, but they did not consider important thinking about socialism other than that." ${ }^{37}$

The dissolution of Yugoslavia and the war experience of the new wave of refugees determined in many ways the greatest change in the perception of Yugoslavia. One should also bear in mind the fact that, from the 1990s, the second generation of

\footnotetext{
${ }^{36}$ Ibid.

${ }^{37}$ Ibid.
} 
community members was growing, whose perception of Yugoslavia was mainly transmitted through the family narrative, the media image of Yugoslavia from the 1990 s and, finally, through a very important fact that the younger generations did not experience life in Yugoslavia. These positions determined polarisation among the Bosniaks in Berlin regarding the new circumstances. Namely, it is necessary for this theme to establish that the structure of the community members changed and that the image of Yugoslavia differentiated among them. Among this inner Bosniak circle, war circumstances brought great changes in relations of different ethnic and religious communities in the way that the existing relations were reduced to very narrow frames. ${ }^{38}$ Furthermore, the different understanding of the situation in Yugoslavia and its dissolution could also be reflected on the everyday life of people who worked in Berlin. One of the interlocutors we interviewed for the purpose of this paper vividly described it. To the question how much the dissolution of Yugoslavia has reflected the relationship between Serbs, Croats, Bosniaks and others in Berlin, the first reaction shows the extent of impact the increased tensions of the Yugoslav dissolution had in Germany.

"Oh, there was bickering at work, when we'd meet, there were all sorts of things, talks, verbal provocations, everyone defended their own. And then it happened in Siemens where I worked, that our superiors saw that a serious incident could break out, since, for some time we'd do a bit hurly burly, brash, many things. And then we were called and warned by the company leadership that if any incident occurred, that there wouldn't be any discussions as to who said what and what was said, who hit whom the first, instead both would be thrown out. That'd be the reason to leave the company and had that occurred it'd have been a serious thing, so then we withdrew to our own cages, kept distance." 39

Within the formed circle of Bosniaks in Berlin, there were also different perceptions of Yugoslavia as there were different ideas about how to organise the community in the new situation. However, the manner in which the abrupt shift of the entire image of Yugoslavia occurred is unique.

"It is unbelievable how swiftly the idea of Yugoslavism faded because of the aggression against Bosnia and Herzegovina. Many people felt to have been betrayed, cheated, because they identified themselves that much with Yugoslavia. At least two groups were formed then. One, which tried to find itself in intensified religiousness, in the return to faith, and, in that way, somehow to recover 'lost time', so that their attitude towards socialism and

\footnotetext{
${ }^{38}$ Interview with B. M, Berlin, July 2013.

${ }^{39}$ Interview with M. K, Berlin, July 2013.
} 
the Yugoslav state was manifested trough the negative perception of atheism, godlessness, considering it to have been a lost time. The second group was very frustrated because of everything that was going on, because the organisation of Bosniaks unfolded through the activities of the Islamic Community and they tried to make clubs - because not everyone was religious, of course. And these clubs were formed. Unfortunately, they do not exist anymore. It was the club Behar, club Ljiljan. And that was the Bosnian-Bosniak reaction to what was going on in the 1990s. But the process of understanding the different levels of identity, Bosnian and the Bosniak, still continues. There are people who up to this day have not understood what it is all about. They haven't understood the issue of writing the word Muslim (in the native language $\mathrm{T} / \mathrm{N}$ ) in the upper, i.e. lower case. But all this is the reaction to the war, to the Serb hegemony over Bosnia and Herzegovina because, in the end, everyone identified with Bosnia." 40

The identification with Bosnia and Herzegovina and dealing with the war experience in critical situations sometimes resulted in observing everything that was Yugoslav exclusively through the prism of the crisis of the country's dissolution. "It was especially the case during the time of suffering. With some people, it a caused negative reaction towards Serbia generally, since they blamed Serbia for the war in Bosnia and Herzegovina. Parents interpreted it to their children through some of their personal traumas and there were displays of rage. But today there are young people who are completely unfamiliar with Yugoslavia. For them, it is an abstract noun, they do not know what it means because they only have the experiences of their parents, and these experiences are connected to the perceptions of their parents. If their parent is Yugo-nostalgic then this is reflected on the child. But to those young people, Yugoslavia is something very unfamiliar. They do not know what it meant living in a country from Triglav to Gevgelija. And the young people born in Germany have a relationship towards Bosnia, not Yugoslavia." ${ }^{41}$

After the situation stabilised and the end of the war in Bosnia and Herzegovina, the Bosnian community in Berlin entered a new phase of life the way that it was looking for new directions of activity, resolving the issue of premises and similar things. Eventually, the end of the war reflected on the changes in the structure of the community members. Many left Berlin for the United States of America, Canada, Australia, and many returned to Bosnia and Herzegovina, but a significant number also remained in Berlin. For the purpose of the further development of the community, it was necessary to institutionalise the relations and setup clear

\footnotetext{
${ }^{40}$ Interview with M. T, Berlin, August 2014.

${ }^{41}$ Ibid.
} 
goals. Today, members of the Centre are proud of their activities in the 1990s and the status they have received in Germany. "We are proud of our support to Bosnia. The support in affirming Bosnia in every respect. Today, when we see how much has been done, how much we have helped, how many problems we have solved, I think that we can be proud. This Centre implanted in people the need to help other people. We help spread the voice about Bosnia because we have guests from Croatia, Serbia, but we also cooperate with the institutions in Germany. At the end, we are proud of everything that we have built in Berlin because, and I cite others who speak about us, 'we set the standards for other Islamic communities." 42

As can be seen throughout this paper, the Yugoslav/Bosnian Muslim community in Berlin, Germany, underwent many identity changes in last 50 years thus making a perfect case study example of identity transformation of Bosnian migrants in Germany regardless of their social, economic or other background. Once established as a community of guest workers in what is today the German capital, the Bosniak community eventually transformed its identity markers due to both German and Yugoslav, as well as post-Yugoslav socio-political contexts. Abovementioned changes led guest workers community to become self-organised and self-conscious Bosniak community whose multi-layered identities underwent changes in major geopolitical game of thrones whose outcomes they still tend to imagine.

\section{Bibliography}

\section{Interviews}

Interview with M. K., Berlin 25 July 2013.

Interview with B. M, Berlin, July 2013.

Interview with M. T, Berlin, August 2014.

\section{Literature}

Bandžović, S. 2006, Iseljavanje Bošnjaka u Tursku. Sarajevo: Institut za istraživanje zločina protiv čovječnosti i međunarodnog prava Univerziteta u Sarajevu.

Ćehić, S. 2010, Hamza gastarbajter. Cazin: Grafis.

Dervišević, A. 2006, Bošnjaci u dijaspori. Problemi, analize i perspektive. SarajevoWuppertal: Bosanska riječ.

Doder, M. 1989, Jugoslovenska neprijateljska emigracija. Zagreb: Centar za informisanje i publicitet.

${ }^{42}$ Ibid. 
Duranović, A. 2015, Islamska zajednica u društveno-političkom životu Bosne $i$ Hercegovine od 1953. do 1974. godine. Sarajevo: Filozofski fakultet Univerziteta u Sarajevu, PhD Thesis.

Imamović, M. 1996, Bošnjaci u emigraciji: Monografija 'Bosanskih pogleda" 1955 1967. Zürich: Bošnjački institut.

Ivanović, V. 2012, Geburtstag pišeš normalno: jugoslovenski gastarbajteri u SR Nemackkoj i Austriji: 1965-1973. Beograd, Institut za savremenu istoriju.

Ивановић, В. 2011, “Субота на банхофу”: Свакодневица југословенских радника на “привременом раду” у СР Немачкој и Аустрији. In: Годишґак за друштвену историју, XVIII/ 1, 2011, pp. 69-87.

Kamberović, H. 2011, "Stav političke elite o nacionalnom identitetu muslimana u Bosni i Hercegovini sredinom 1960-ih godina”. In: Hod po trnju, iz bosanskohercegovacke historije 20. stoljeća, 180-208.

Kelly, L. 2003, “Bosnian Refugees in Britain: Questioning Community”, Sociology, Vol. 31 (I), pp. 35-49.

Mahmutović, M. 2003, Džemati Bošnjaka u dijaspori. Sarajevo: Rijaset Islamske zajednice u Bosni i Hercegovini, Ured za bošnjačku dijasporu.

Мандић, М. 2018, “Како су ьуди долазили у Берлин? Аичне мреже у Аискурсу миграната бошњачке национацности", Гласник Етнографског института CAHYLXV (3), 547-580.

Paul, J. 2016, "Bosnian Organizations in Germany: Orientations and Activities in Transnational Social Spaces", (COMCAD Working Papers, 149). Bielefeld: Universität Bielefeld, Fak. für Soziologie, Centre on Migration, Citizenship and Development (COMCAD).

Pezo, E. 2013, Zwangsmigration in Friedenszeiten? Jugoslawische Migrationspolitik und die Auswanderung von Muslimen in die Türkei (1918 bi 1966), Südosteuropäische Arbeiten, 146, Oldenbourg Verlag.

Von Oppen, K. 2006, “Imagining the Balkans, Imagining Germany: Intellectual Journeys to Former Yugoslavia in the 1990s", The German Quarterly, Vol. 79, No. 2, pp. 192-210. 